\title{
CONGENITAL PROLAPSE PICTURE OF THE MONTH
}

\author{
L. S. Deshmukh ${ }^{1}$, Varsha Deshmukh², Kanan Yeliker³, Ismail Mulla ${ }^{4}$
}

\section{HOW TO CITE THIS ARTICLE:}

L. S. Deshmukh, Varsha Deshmukh, Kanan Yeliker, Ismail Mulla. "Congenital Prolapse Picture of the Month". Journal of Evolution of Medical and Dental Sciences 2014; Vol. 3, Issue 16, April 21; Page: 4360-4362,

DOI: $10.14260 /$ jemds/2014/2442

ABSTRACT: Neonatal prolapse is a rare condition occurring first few days of birth. First case of neonatal prolapsed was reported in 1723 by Conovius ${ }^{1}$. Today very few cases of neonatal prolapsed are reported. We hereby report a very rare case of neonatal prolapse.

KEYWORDS: Neonatal genital prolapse, Congenital genital prolapse.

INTRODUCTION: Genital prolapse in newborn is a rare condition, usually associated with spina bifida. Following case is of a baby with Congenital genital prolapsed with spina bifida. Although genital prolapse in a newborn is rare, it is well documented. It may be associated with weakening of pelvic supporting tissue resulting from faulty innervations due to spina bifida.

CASE REPORT: A married woman, aged 22 yrs. was referred to labor room at 36 weeks as primigravida with breech presentation. She was married since 2 yrs. There was history of consanguineous marriage with the second cousin. On examination her general condition was uneventful, the height of uterus was full term with breech presentation, and fetal heart rate was regular. On per-vaginal examination her cervix was $2.5 \mathrm{~cm}$ dilated, $40 \%$ effaced, membranes present, station high pelvis adequate. Hb-11 gm\%, Urine Albumin-Nil \& Blood group is B + Ve.

A Lower Segment Caesarian Section was carried out under spinal anesthesia. Indication for LSCS was Primi with Breech. The baby was extracted by breech. Intra-operative \& post-operative period was uneventful. The Neonatologist labeled the patient as 'female child with spina bifida with congenital prolapse with SGA' and admitted to NICU.

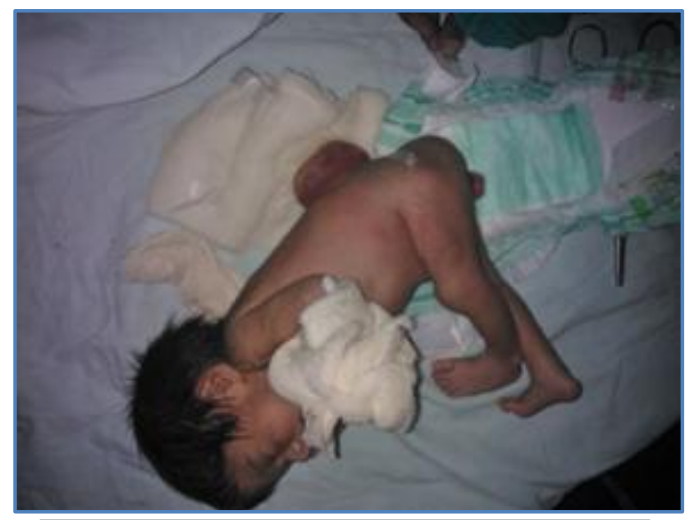

Fig. 1: Meningomyelocele with congenital prolapse

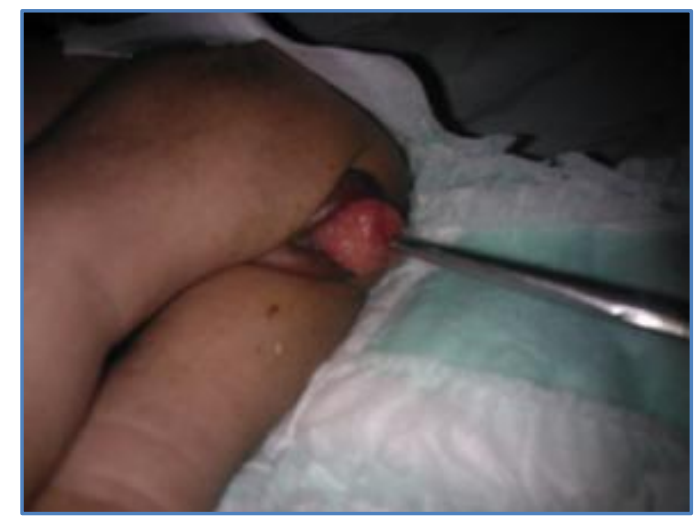

Fig. 2: Showing cervical os

Physical examination confirmed the diagnosis, digital reduction was done \& patient referred for pediatric surgery for further management for the repair of the meningomylocele. 
DISCUSSION: Uterine prolapse is the condition normally associated with multiparity in postmenopausal women; however it is very rare \& difficult to diagnose and treat this condition in neonatal period. It carries risk of morbidity with progressing time in the newborn baby having numerous neurological, muscular \&spinal abnormalities. Recently new method of treatment with pessary reduction has been reported. ${ }^{2}$ Genital prolapse occurs when pelvic organs slip from normal anatomical position $\&$ protrude into vaginal wall.

Various degrees of vaginal genital prolapse have been reported ranging from total genital prolapse to a lesser degree of prolapse. The congenital genital prolapse represents the defect in the musculature of the pelvic floor. The D/D in this includes urethral prolapse, urethrocele, vaginal introitus cyst, urogenital sarcoma \& genital prolapse 3 .

In the above case the genital prolapse was associated with Meningomyelocele \& spina bifida. Spina bifida is the most frequently co-existing anomaly in congenital prolapsed (50\%). ${ }^{4}$ The association of meningomylocele \& the congenital anomaly of spine result in the pelvic floor weakness as a consequences of disturbed sacral innervations. ${ }^{5}$

The conservative management which is advocated is the single or repeated digital reduction, use of hypertonic saline pads, vaginal pessary \& insertion of Foleys catheter into the vagina. ${ }^{5}$

CONCLUSION: We report this case of neonatal genital prolapse because of its uncommon \& rare presentation. Throughout the lifetime, a gynecologist may or may not see this condition because of its rarity. Although nothing much could be done in this case, the awareness of the occurrence of congenital genital prolapsed is created through this report.

\section{REFERENCES:}

1. J. B. Ellls, E. G. M. Boes. Genital prolapse- A case report in the neonate. SAMT DEEL 6921 JUNIE 1986-836.

2. M. H. Mehta, R. V. Patel, Y.C. Bhatt, Leela Mehta. Neonatal Uterine Prolapse. The Indian Journal of Pediatrics. September-October 1992, Volume 59, Issue 5, pp 644-646.

3. Johnson A, Unger SW, Rodgers BM. Vaginal prolapse. Pediatric Surgery Update 8 Vol 24(1): Jan, 2005.

4. P. J. Cheng, S. W. Shaw, H. Y. Cheuh, Y. K. Soong. Picture of the Month. Ultrasound Obstet Gynecol 2005; 26: 204-206.

5. K. Fathi, A. Pinter. Semiconservative Management of Neonatal Vaginal Prolapse. Journal of Pediatric Surgical Specialties. December 2008 ; Vol 2, No.3 : 40-41. 


\section{CASE REPORT}

\section{AUTHORS:}

1. L. S. Deshmukh

2. Varsha Deshmukh

3. Kanan Yeliker

4. Ismail Mulla

\section{PARTICULARS OF CONTRIBUTORS:}

1. Professor, Department of Neonatology, GMCH, Aurangabad.

2. AP \& Unit Head, Department of Obstetrics and Gynaecology, GMCH, Aurangabad.

3. Professor and HOD, Department of Obstetrics and Gynaecology, GMCH, Aurangabad.
4. Junior Resident II, Department of Obstetrics, and Gynaecology, GMCH, Aurangabad.

\section{NAME ADDRESS EMAIL ID OF THE} CORRESPONDING AUTHOR:

Dr. Varsha Deshmukh,

Plot No. 120, Samarth Nagar,

Aurangabad.

E-mail: deshmukhvl@yahoo.com

Date of Submission: $12 / 03 / 2014$.

Date of Peer Review: 13/03/2014.

Date of Acceptance: 22/03/2014.

Date of Publishing: 21/04/2014. 